Article

\title{
Descriptive Statistical Analysis of Vegetable Oil Combustion in a Commercial Burner to Establish Optimal Operating Conditions
}

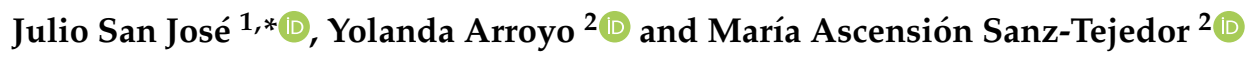 \\ 1 Department of Energy Engineering and Fluid Mechanics, ITAP, School of Industrial Engineering, \\ University of Valladolid, Paseo del Cauce, 59, 47011 Valladolid, Spain \\ 2 Department of Organic Chemistry, ITAP, School of Industrial Engineering, Universidad de Valladolid, \\ Paseo del Cauce, 59, 47011 Valladolid, Spain; yarroyo@eii.uva.es (Y.A.); atejedor@eii.uva.es (M.A.S.-T.) \\ * Correspondence: julsan@eii.uva.es
}

Received: 6 May 2019; Accepted: 19 June 2019; Published: 20 June 2019

\begin{abstract}
This article studies the combustion of refined sunflower, virgin sunflower and virgin rapeseed oils in a low-pressure auxiliary air fluid pulverization burner in order to establish the optimal operating conditions. The influence of varying the type of vegetable oil, fuel flow rate and secondary airflow rate in the combustion process was analyzed. These three factors are independent in the combustion process, which means having to carry out numerous assays, combining the various factors with one another. Given the amount of variables to be optimized and the existence of three factors, a statistical approach is adopted to help interpret the results obtained and to evaluate how each factor influences the combustion results. Optimal combustion is determined based on three criteria, minimum pollutant emissions ( $\mathrm{CO}, \mathrm{NOx}$ and $\mathrm{CxHy}$ ), maximum combustion performance, and minimum excess air. The result of this study showed that airflow was the principal factor affecting emissions, whereas for combustion performance, both factors (airflow and fuel flow) were determinant. In general, admissible combustion performances were obtained, with $\mathrm{CO}$ and NOx emissions below permitted levels. The best combustion performance was achieved under conditions of maximum fuel flow and minimum airflow rates.
\end{abstract}

Keywords: rapeseed oil; sunflower oil; biofuel; combustion; burner; descriptive statistical analysis

\section{Introduction}

Combustion of vegetable oils (VOs) for heating purposes in industrial and domestic boilers has proven to be a viable alternative to fossil fuel resources. One of the advantages of burning VOs is the low NOx and SOx emissions due to the virtually non-existent nitrogen and sulfur content in VOs [1], although NOx production also depends on the flame temperature reached in the combustion chamber. Moreover, in countries which lack oil resources, this process helps to put agricultural surpluses to good use. Nevertheless, the combustion of VOs in conventional burners indicates a number of limitations due to their high viscosity and low volatility, which could give rise to poor atomization and incomplete combustion. One alternative used to reduce the viscosity of VOs is to transform them into the corresponding methyl esters (FAME), through a reaction with methanol in basic medium. In this regard, several authors have performed combustion of pure biodiesel in several types of boilers: Bazooyar in a semi-industrial boiler, studied different areas: economic feasibility [2], the possibility of reducing NO emissions [3], combustion of biodiesel in utility power plant boilers [4] and the combustion performance of biodiesel in a semi-industrial boiler [5]. In addition, Pereira used a large-scale laboratory furnace [6], Kermes burned biodiesel (EN 14213) in a light heating oil in a 1 MW 
stationary combustion facility [7], Macor studied combustion performance of biodiesel in a boiler for residential heating [8], and Tashtoush analyzed the emission and combustion performance of biodiesel from a waste vegetable oils, in a water-cooled furnace [9]. Other authors studied the combustion of biodiesel and fuel mixtures: Ghorbani using a semi-industrial-boiler, studied the combustion of soybean oil methyl ester and biodiesel blends with petrodiesel [10,11], Ng studied the combustion of palm oil biodiesel blends [12], Al-Kassil analyzed the combustion of biodiesel/diesel mixture in a domestic heating boiler [13] and in a mechanical pulverization burner [14], and eventually, Lee analyzed possible emission reductions from the combustion of soy oil biodiesel blended with diesel fuel. [15]. Published results showed that low CO emissions coupled with good performance could be obtained, although NOx emissions were difficult to control and could vary considerably depending on the burner operating conditions. Another option for reducing viscosity of VOs involves mixing them with petroleum derived fuels, which are less viscous. Using a mechanical pulverization burner, San José et al. studied the combustion of mixtures of sunflower (SfO) $[16,17]$, soya (SyO) $[18,19]$ and rapeseed oils (RpO) [20], as well as animal fat waste [21] with diesel fuel. Using mixtures of diesel fuel (fossil)-vegetable oil (VO) (3:2) they obtained combustion performances of up to $85 \%$ and NOx emissions below $53 \mathrm{ppm}$. The same authors then showed that the use of a low-pressure auxiliary air pulverization burner allowed the direct combustion of VOs without the need to mix them with petroleum derivatives to reduce their viscosity [22]. The burner operates with injection pressures of $1 \times 10^{5} \mathrm{~Pa}$, and the VO, if it is liquid at room temperature, can be fed into the combustion chamber without the need for pre-heating. Combustion of VOs with different fatty acids (FA) in this burner yields good performance and NOx emissions below 46 ppm [23,24]. Recently, our research team studied the features of the atomization process and subsequent combustion of refined palm oil (P1O), in the previously mentioned emulsion burner [25]. In most of the tests carried out, the authors observed that the lower the spray cone angle, the greater the combustion performance.

Unlike other studies described in the literature, in this work a statistical method is applied, which allows the influence of the factors (burner control parameters and type of VOs) on the emissions and on combustion performance to be determined. Since it cannot be assumed that the parameters which optimize the combustion will follow the same trend, it is difficult to conduct a purely comparative analysis, as has been carried out until now.

This work explores the combustion of three vegetable oils, two virgin oils: sunflower (VSfO) and rapeseed oils (VRpO) and one refined, sunflower oil (RSfO). The experimental facility consists of an AR-CO (BR 5) commercial burner, which allows fuels with viscosities ranging from 26 to $112 \mathrm{~mm}^{2} \cdot \mathrm{s}^{-1}$ (the manufacturer characterizes the burner with a fuel at $50{ }^{\circ} \mathrm{C}$ ) to be burned. The burner adjustment is specific to each oil and it is necessary to regulate the fuel flow supplied to the burner and the secondary airflow to achieve optimal combustion. As a result, the factors studied are the type of oil, the airflow and the fuel flow rates. The influence of each factor in the combustion results is studied using a descriptive statistical analysis of the mean value of each combustion variable (CO, NOx CxHy and combustion performance). Additionally, the burner's optimal operating conditions for achieving the best combustion performance with the lowest polluting emissions were established through this study.

\section{Materials and Methods}

\subsection{Combustion Equipment and Procedure}

Combustion of VOs is performed in a commercial AR-CO model BR 5 burner. This burner uses the auxiliary air (secondary air) to lower the viscosity of the vegetable oil and improve the spraying process. The experimental facility is located in the Industrial Heating and Cooling Laboratory at the University of Valladolid. A photographic view of the experimental setup is shown in Figure 1. In addition to the burner, the facility includes a combustion chamber connected to a chimney in which the gas analyzer is inserted, a blower to control the combustion chamber temperature and two feeder tanks. 
One of the tanks contains diesel fuel and is used to reach a steady state. The other contains the VO to be tested and is equipped with a probe and an electric resistance to keep the temperature constant.

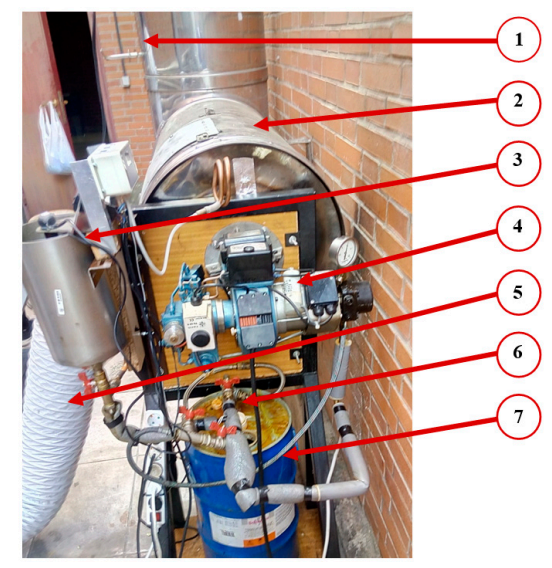

Figure 1. Photograph of the experimental facility. 1: Gas analyzer; 2: Combustion chamber; 3: Oil tank equipped with temperature control; 4: Burner; 5: Refrigeration air; 6: Valve system; 7: Diesel fuel tank.

Emissions of $\mathrm{O}_{2}, \mathrm{CO}, \mathrm{NOx}, \mathrm{SOx}$ and unburned hydrocarbons, $\mathrm{CxHy}$, as well as flue gas temperature are directly measured in a TESTO $350 \mathrm{M} / \mathrm{XL}$ gas analyzer, which has previously been calibrated. The technical characteristics of this analyzer are shown in Table 1.

Table 1. Technical characteristics of the Testo 350M/XL Gas Analyzer.

\begin{tabular}{cccc}
\hline Parameter (Sensor) & Measuring Range & Accuracy & Resolution \\
\hline oxygen, $\mathrm{O}_{2}$ (electrochemical) & $0-25 \%$ & $\pm 0.2 \%$ & $0.01 \%$ \\
carbon monoxide ${ }^{1}, \mathrm{CO}$ (ibid) & $0-500 \mathrm{ppm}$ & $\pm 2 \mathrm{ppm}(<40 \mathrm{ppm}) ;$ & $0.1 \mathrm{ppm}$ \\
& & $\pm 5 \%(<500 \mathrm{ppm})$ & $\pm 5 \mathrm{ppm}(<99 \mathrm{ppm}) ;$ \\
nitrogen oxides, $\mathrm{NO}, \mathrm{NOx}$ (ibid) & $0-3000 \mathrm{ppm}$ & $\pm 5 \%(<2000 \mathrm{ppm})$ & $1 \mathrm{ppm}$ \\
sulfur dioxide, $\mathrm{SO}_{2}$ (ibid) & $0-1450 \mathrm{ppm}$ & $\pm 5 \mathrm{ppm}(<100 \mathrm{ppm})$ & $1 \mathrm{ppm}$ \\
total hydrocarbons, $\mathrm{C}_{\mathrm{X}} \mathrm{H}_{\mathrm{Y}}$ (ibid) & $0-6000 \mathrm{ppm}$ & $\pm 10 \%$ of reading & $10 \mathrm{ppm}$ \\
flue gases temperature, $\mathrm{T}_{\mathrm{g}}$ & -40 to $1200^{\circ} \mathrm{C}$ & $\pm 0.5 \%\left(<100{ }^{\circ} \mathrm{C}\right)$ & $1.0 \pm 0.3 \%$ of reading \\
\hline
\end{tabular}

${ }^{1} \mathrm{H}_{2}$ compensated.

In addition, $\mathrm{CO}_{2}$ emissions was calculated as shown in Equation (1):

$$
\left(\mathrm{CO}_{2}\right)=[1.8 \hat{6} \cdot[\mathrm{C}]] /\left[\left[(\lambda-1) \cdot V^{0}{ }_{\text {air }}\right]+V_{g}^{0}\right]
$$

where excess air $(\lambda)$ was determined based on the $\mathrm{O}_{2}$ concentration in flue gas [26], read by the gas analyzer.

$[C]$ is the $\mathrm{kg}$ of carbon per $\mathrm{kg}$ of fuel in the VO. This value was determined as ASTM 5291 standard method (Table 2).

$V^{0}{ }_{a i r}$ the volume of stoichiometric air per $\mathrm{kg}$ of fuel, and $V_{g}^{0}$ the volume of stoichiometric flue gas per $\mathrm{kg}$ of fuel. Both parameters were calculated as procedure described in [26].

The combustion performance $(\eta)$ compared to the lower heating value $(L H V)$ was defined as:

$$
\eta=\left(1-\frac{C p_{g} \cdot m^{1} g \cdot\left(t_{g}-t_{\text {air. }}\right)}{L H V}\right) \cdot 100
$$

where, $C p_{g}$ means specific heat of flue gases at constant pressure for flue gas temperature $\left(\mathrm{kJ} / \mathrm{kg}_{\text {fuel }}{ }^{\circ} \mathrm{C}\right)$, $\mathrm{m}_{\mathrm{g}}^{1}$ mass of non-stoichiometric flue gas per $\mathrm{kg}$ of combustible. Both parameters were calculated as procedure described in $[24,26]$. 
$t_{a}$ and $t_{g}$ are combustion air temperature and flue gas temperature at output, in $\left({ }^{\circ} \mathrm{C}\right)$, respectively. Both variables were measured directly in gas analyzer.

Table 2. Characteristics of the Vegetable Oils studied.

\begin{tabular}{cccccc}
\hline Characteristics & Unit & VSfO & RSfO & VRpO & Standard \\
\hline $\mathrm{C}(\%)$ & $\%\left(\mathrm{~m} \cdot \mathrm{m}^{-1}\right)$ & 76.5 & 76.0 & 77.5 & ASTM 5291 \\
$\mathrm{H}(\%)$ & $\%\left(\mathrm{~m} \cdot \mathrm{m}^{-1}\right)$ & 11.2 & 11.3 & 11.4 & ASTM 5291 \\
$\mathrm{N}(\%)$ & $\%\left(\mathrm{~m} \cdot \mathrm{m}^{-1}\right)$ & $<0.03$ & $<0.03$ & $<0.03$ & ASTM 5291 \\
$\mathrm{S}(\%)$ & $\%\left(\mathrm{~m} \cdot \mathrm{m}^{-1}\right)$ & $<0.02$ & $<0.02$ & $<0.02$ & ASTM 1552 \\
$\mathrm{O}^{1}(\%)$ & $\%\left(\mathrm{~m} \cdot \mathrm{m}^{-1}\right)$ & 12.2 & 12.6 & 11.0 & - \\
ash $(\%)$ & $\%\left(\mathrm{~m}^{-1} \cdot \mathrm{m}^{-1}\right)$ & 0.011 & 0.006 & 0.026 & EN 6245 \\
acidity $(\%)$ & $\%\left(\mathrm{~m}^{-1}\right)$ & 2.03 & 0.02 & 0.77 & ISO 660 \\
humidity $(\%)$ & $\%\left(\mathrm{~m} \cdot \mathrm{m}^{-1}\right)$ & 0.09 & 0.01 & 0.10 & ISO 662 \\
density at $15^{\circ} \mathrm{C}$ & $\mathrm{kg} \cdot \mathrm{m}^{-3}$ & 923.3 & 923.5 & 920.1 & ISO 12185 \\
density at $35^{\circ} \mathrm{C}$ & $\mathrm{kg} \cdot \mathrm{m}^{-3}$ & 910.0 & 909.6 & 906.9 & ISO 12185 \\
density at $60^{\circ} \mathrm{C}$ & $\mathrm{kg} \cdot \mathrm{m}^{-3}$ & 893.1 & 892.6 & 890.0 & ISO 12185 \\
kinematic viscosity at $40{ }^{\circ} \mathrm{C}$ & $\mathrm{mm} \cdot \mathrm{s}^{-1}$ & 31.80 & 32.78 & 35.62 & ISO 3104 \\
kinematic viscosity at $100{ }^{\circ} \mathrm{C}$ & $\mathrm{mm} \cdot \mathrm{s}^{-1}$ & 7.61 & 7.77 & 7.96 & ISO 3104 \\
H.H.V. & $\mathrm{kJ} \cdot \mathrm{kg}^{-1}$ & 39309 & 39405 & 39564 & ASTM 240 \\
L.H.V. & $\mathrm{kJ} \cdot \mathrm{kg}^{-1}$ & 36932 & 37007 & 37146 & ASTM 240 \\
\hline
\end{tabular}

${ }^{1}$ Estimated by difference.

In an effort to ensure the experimental results were obtained in the same facility operating conditions, a test method previously described by our research group was used [24]. Once the facility was put into a steady state with diesel, the burner operation parameters were established (fuel and air flow rates) and the facility was run with the VO pre-heated to $40{ }^{\circ} \mathrm{C}$ for about two minutes until steady state was reached. At this point, test data were read using the gas analyzer. After recording the data in the initial operating conditions, the operating parameters of the set-up were changed and data were taken for each of the scheduled tests. Once the programmed tests had been completed, the burner was fed with diesel fuel to clean the pipes and the session was concluded. The process is shown in the diagram in Figure 2.

In all the experiments carried out, the pressure of the fuel injection pump was kept constant at 80 $\mathrm{kPa}$, and the combustion chamber works with an overpressure of $20 \mathrm{~Pa}$.

\subsection{Physicochemical Characterization and Fatty Acids Profile of the VOs}

The VOs produced in Spain from oleaginous plants are RpO and SfO. Both VOs were studied in this work in their virgin form, VRpO and VSfO, as well as their refined form RSfO. These VOs were supplied by the ACOR Oils and Oilseeds Processing Plant, at Olmedo a small town located $150 \mathrm{~km}$ north of Madrid, Spain.

The elemental analysis and physicochemical properties of these VOs are shown in Table 2 and were determined at the Castilla y León Regional Fuel Laboratory (LARECOM). The highest viscosity values, highest heating value and highest percentage of carbon correspond to VRpO. Nitrogen and sulfur content is negligible in all cases $(<0.03 \%$ and $0.02 \%$, respectively), given that VOs contain no organic nitrogen and sulfur compounds.

The fatty acid profile of each VO was determined using a gas chromatography technique in accordance with ISO 12966. As can be seen in Table 3, the main components are Oleic, C18:1, Linoleic, C18:2, Linolenic, C18:3 and the saturated fatty acids, Palmitic, C16:0 and Stearic, C18:0. For VSfO and $\mathrm{RSfO}$, the principal FA is linoleic ( $61.9 \%$ and $58.5 \%$, respectively) followed by oleic ( $25.3 \%$ and $29.5 \%$, respectively). As a result, both evidence a high degree of unsaturation (DU): 149.8 for VSfO and 147.1 for RSfO. Of the three VOs, VRpO displays the highest percentage of linolenic (7.6\%), although its principal FA is oleic $(62.9 \%)$. As a result, its DU is slightly lower than the former, displaying a value of 127.8. The three VOs evidence a low content of saturated FAs $(\mathrm{S} \leq 12.1 \%)$. 


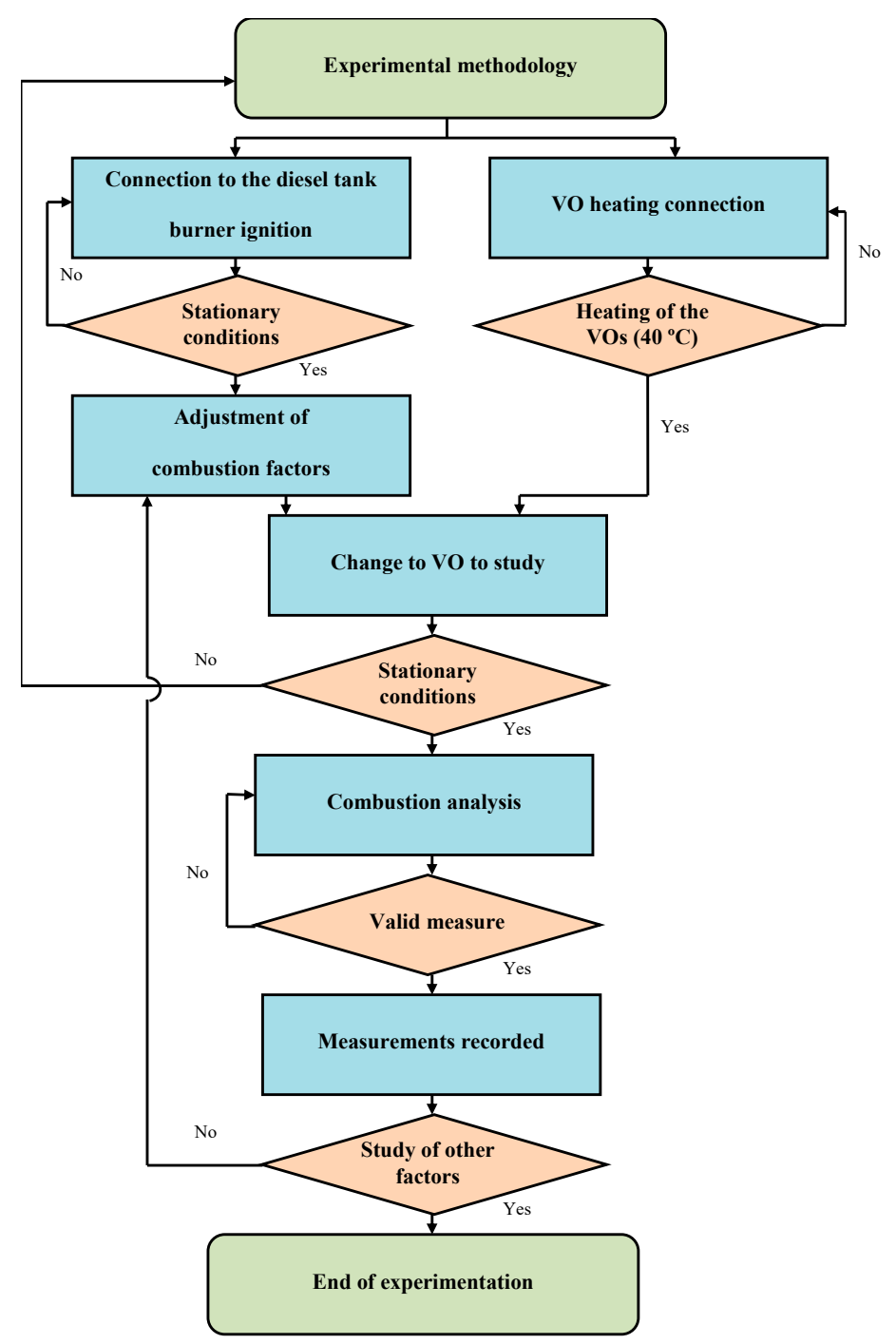

Figure 2. Block diagram of the combustion test methodology process.

Table 3. Fatty acid composition $\left(\% \mathrm{~m} \cdot \mathrm{m}^{-1}\right)$ obtained by gas chromatography for VSfO, RSfO and VRpO.

\begin{tabular}{|c|c|c|c|c|}
\hline Fatty Acid & Carbons: Unsaturations & VSfO & RSfO & VRpO \\
\hline Myristic & C14:0 & 0.07 & 0.07 & 0.05 \\
\hline Palmitic & C16:0 & 6.1 & 6.0 & 4.6 \\
\hline Palmitoleic & C16:1 & 0.1 & 0.1 & 0.2 \\
\hline Margaric & $\mathrm{C} 17: 0$ & 0.04 & 0.04 & 0.05 \\
\hline Stearic & C18:0 & 4.3 & 4.1 & 1.7 \\
\hline Oleic & C18:1 & 25.3 & 29.5 & 62.9 \\
\hline Linoleic & C18:2 & 61.9 & 58.5 & 20.3 \\
\hline Linolenic & C18:3 & 0.12 & 0.1 & 7.6 \\
\hline Arachidic & C20:0 & 0.32 & 0.3 & 0.6 \\
\hline Gadoleic & C20:1 & 0.2 & 0.2 & 1.2 \\
\hline Behenic & $\mathrm{C} 22$ & 1.0 & 0.8 & 0.3 \\
\hline Lignoceric & $\mathrm{C} 24$ & 0.3 & 0.3 & 0.1 \\
\hline trans isomers & - & - & 0.31 & - \\
\hline Sterols (ppm) & - & 3816 & 3201 & 8650 \\
\hline Wax (ppm) & - & 454 & 75 & - \\
\hline $\mathrm{UD}^{1}(\%)$ & - & 149.8 & 147.1 & 127.8 \\
\hline
\end{tabular}




\section{Results and Discussion}

\subsection{Experimental Design}

Tests were carried out selecting two fuel flow rates $(\mathrm{C} 3, \mathrm{C} 6)$ and two secondary airflows (Amin, Amid). Secondary air flow can be adjusted by a fan dumper setting which controls the amount of air entering the combustion chamber. The fuel flows determined, in $\mathrm{kg} \mathrm{h}^{-1}$, for VSfO, RSfO and VRpO were, respectively, 6.1, 5.9 and 6.1 for C3, and 7.1, 6.9 and 7.1 for C6, respectively. The values of secondary airflows, in $\mathrm{m}^{3} \cdot \mathrm{h}^{-1}$ are: 131.77 for Amin and 138.4 for Amid. The values of secondary airflows, in $\mathrm{m}^{3} \cdot \mathrm{h}^{-1}$ are: 131.77 for Amin and 138.4 for Amid.

Both factors (fuel flow rate and airflow) were considered independent, and for each VO two fuel flow rates (C3 and C6) and two airflows (Amin and Amid) were studied. A total of thirty six different tests were performed, four for each VO. Three measurements were taken in each of the burner operating conditions in order to obtain the mean value, $\mu$, the standard deviation, $\sigma$, and the coefficient of variation $(\mathrm{CV})$ (defined as the ratio between the standard deviation and the mean value). Table 4 shows the response variables obtained experimentally for each of the VOs tested. $\mathrm{SO}_{2}$ emissions were not included since values below 1 ppm were obtained in all the tests performed. The $\mathrm{CO}_{2}$ emissions calculated ranged between $7.50 \%$ and $8.94 \%$, although since VOs are a renewable energy source, these emissions only contribute minimally to global warming.

Table 4. Variations of Gas Emissions and $\eta$ with Fuel Flow and Secondary Airflow of the three VOs studied (mean values, standard deviation and coefficient of variation).

\begin{tabular}{|c|c|c|c|c|c|c|c|c|c|c|c|c|c|}
\hline & & \multicolumn{12}{|c|}{ Fuel Flow-Airflow } \\
\hline & & \multicolumn{3}{|c|}{ C3-Amin } & \multicolumn{3}{|c|}{ C3-Amid } & \multicolumn{3}{|c|}{ C6-Amin } & \multicolumn{3}{|c|}{ C6-Amid } \\
\hline \multicolumn{14}{|c|}{ measured values } \\
\hline $\begin{array}{c}\text { Gas } \\
\text { emissions }\end{array}$ & VOs & $\mu$ & $\sigma$ & CV (\%) & M & $\sigma$ & CV (\%) & $\mu$ & $\sigma$ & CV (\%) & $\mu$ & $\sigma$ & CV $(\%)$ \\
\hline \multirow{3}{*}{$\mathrm{O}_{2}, \%$ vol } & VSfO & 11.08 & 0.33 & 2.93 & 10.91 & 0.09 & 0.87 & 9.62 & 0.62 & 6.44 & 10.43 & 0.14 & 1.29 \\
\hline & RSfO & 11.5 & 0.09 & 0.78 & 11.34 & 0.16 & 1.41 & 10.03 & 0.17 & 1.65 & 10.59 & 0.11 & 1.09 \\
\hline & VRpO & 10.96 & 0.79 & 7.17 & 11.43 & 0.38 & 3.28 & 9.50 & 0.03 & 0.37 & 9.96 & 0 & 0 \\
\hline \multirow{3}{*}{$\mathrm{CO}, \mathrm{ppm}$} & VSfO & 19.50 & 4.50 & 2.33 & 121.00 & 0 & 0 & 216.00 & 21.00 & 9.72 & 147.50 & 5.50 & 3.73 \\
\hline & $\mathrm{RSfO}$ & 216.50 & 1.50 & 0.69 & 146.00 & 1.00 & 0.68 & 232.00 & 6.00 & 2.59 & 158.00 & 1.00 & 0.63 \\
\hline & VRpO & 182.00 & 10.00 & 5.49 & 133.00 & 2.00 & 1.50 & 203.00 & 4.00 & 1.97 & 117.00 & 7.00 & 5.98 \\
\hline \multirow{3}{*}{ NOx, ppm } & VSfO & 29.50 & 0.50 & 1.69 & 44.50 & 0.50 & 1.12 & 32.00 & 0 & 0 & 41.50 & 0.50 & 1.20 \\
\hline & RSfO & 31.00 & 0 & 0 & 40.00 & 0 & 0 & 29.00 & 0 & 0 & 39.00 & 2.00 & 5.13 \\
\hline & VRpO & 30.00 & 1.00 & 3.33 & 46.50 & 0.50 & 1.08 & 32.00 & 0 & 0 & 45.00 & 0 & 0 \\
\hline \multirow{3}{*}{ CxHy, ppm } & VSfO & 225.00 & 5.00 & 2.22 & 175.00 & 5.00 & 2.86 & 150.00 & 20.00 & 13.33 & 125.00 & 5.00 & 4.00 \\
\hline & RSfO & 195.00 & 5.00 & 2.56 & 200.00 & 30.00 & 15.00 & 155.00 & 5.00 & 3.23 & 230.00 & 10.00 & 4.35 \\
\hline & VRpO & 190.00 & 10.00 & 5.26 & 195.00 & 15.00 & 7.69 & 155.00 & 15.00 & 9.68 & 175.00 & 35.00 & 20.00 \\
\hline \multirow{3}{*}{$t_{a}{ }^{1},{ }^{\circ} \mathrm{C}$} & VSfO & 29.2 & 1.0 & 3.39 & 30.2 & 1.7 & 5.62 & 32.3 & 0.4 & 1.31 & 30.4 & 0.4 & 1.39 \\
\hline & RSfO & 31.6 & 0.6 & 2.01 & 32.4 & 0.1 & 0.44 & 30.7 & 0.4 & 1.38 & 31.1 & 0.6 & 1.82 \\
\hline & VRpO & 32.3 & 0.8 & 2.41 & 31.2 & 0.1 & 0.23 & 30.4 & 0.1 & 0.46 & 31.8 & 0.07 & 0.22 \\
\hline \multirow{3}{*}{$t_{g}{ }^{2},{ }^{\circ} \mathrm{C}$} & VSfO & 398.45 & 6.75 & 1.69 & 437.30 & 2.10 & 0.48 & 456.45 & 13.35 & 2.92 & 452.35 & 3.75 & 0.83 \\
\hline & RSfO & 396.75 & 1.15 & 0.29 & 430.65 & 3.65 & 0.85 & 432.90 & 9.60 & 2.22 & 448.95 & 2.85 & 0.63 \\
\hline & VRpO & 401.95 & 22.45 & 5.59 & 410.55 & 9.15 & 2.23 & 430.7 & 4.00 & 0.93 & 454.55 & 0.75 & 0.16 \\
\hline \multicolumn{14}{|c|}{ calculated values } \\
\hline \multirow{3}{*}{$\lambda$} & VSfO & 1.99 & 0.06 & 2.90 & 1.96 & 0.02 & 0.84 & 1.76 & 0.09 & 4.90 & 1.88 & 0.02 & 1.14 \\
\hline & RSfO & 2.07 & 0.02 & 0.83 & 2.01 & 0.03 & 1.44 & 1.82 & 0.02 & 1.34 & 1.90 & 0.02 & 0.98 \\
\hline & VRpO & 1.98 & 0.14 & 6.92 & 2.05 & 0.07 & 3.45 & 1.74 & 0.00 & 0.27 & 1.81 & 0 & 0 \\
\hline \multirow{3}{*}{$\mathrm{CO}_{2}, \%$ vol } & VSfO & 7.88 & 0.24 & 2.99 & 8.01 & 0.07 & 0.86 & 8.94 & 0.45 & 5.06 & 8.36 & 0.10 & 1.18 \\
\hline & $\mathrm{RSfO}$ & 7.59 & 0.07 & 0.86 & 7.82 & 0.12 & 1.48 & 8.66 & 0.12 & 1.39 & 8.25 & 0.08 & 1.01 \\
\hline & VRpO & 7.83 & 0.56 & 7.13 & 7.50 & 0.27 & 3.55 & 8.87 & 0.03 & 0.28 & 8.54 & 0 & 0 \\
\hline \multirow{3}{*}{$\eta, \%$} & VSfO & 71.92 & 0.43 & 0.60 & 69.62 & 0.24 & 0.35 & 72.12 & 0.76 & 1.06 & 70.05 & 0.17 & 0.24 \\
\hline & RSfO & 70.91 & 0.24 & 0.35 & 69.40 & 0.27 & 0.39 & 72.60 & 0.23 & 0.32 & 69.88 & 0.12 & 0.18 \\
\hline & VRpO & 71.69 & 0.72 & 1.01 & 69.44 & 0.57 & 0.82 & 73.54 & 0.15 & 0.21 & 70.82 & 0.05 & 0.07 \\
\hline
\end{tabular}

The highest CO emissions were obtained in the combustion of RSfO (232 ppm for C6/Amin) although these values are below the maximum allowed by European legislation [27] (300 ppm). NOx 
emissions ranged between 29 and $47 \mathrm{ppm}$ in all the tests performed, these values being well below the maximum allowed by directive 2010/75/EU (150 ppm). Emissions of CxHy also fall within the permitted range of values, ranging between 125 and $230 \mathrm{ppm}$.

\subsection{Descriptive Statistical Analysis}

A descriptive statistical analysis of the results was conducted establishing three premises on the response variable: obtaining the highest concentration of $\mathrm{CO}_{2}$ (equivalent to performing combustion with the lowest possible excess air), emissions of $\mathrm{CO}$, NOx and $\mathrm{CxHy}$ should be as low as possible, given their harmful effects to the environment and, finally, combustion performance should be as high as possible.

The factors used in the study were the following: the type of vegetable oil, secondary airflow, and fuel flow rates. This study analyzed how these factors affected the combustion response variables in accordance with the previously established premises. First, all the factors were considered to be significant in the response variables. Figure 3 shows how the emissions of each polluting gas (CO, $\mathrm{NOx}$ and $\mathrm{CxHy}$ ) as well as the combustion performance varied for the three VOs depending on the different operating conditions for the burner.
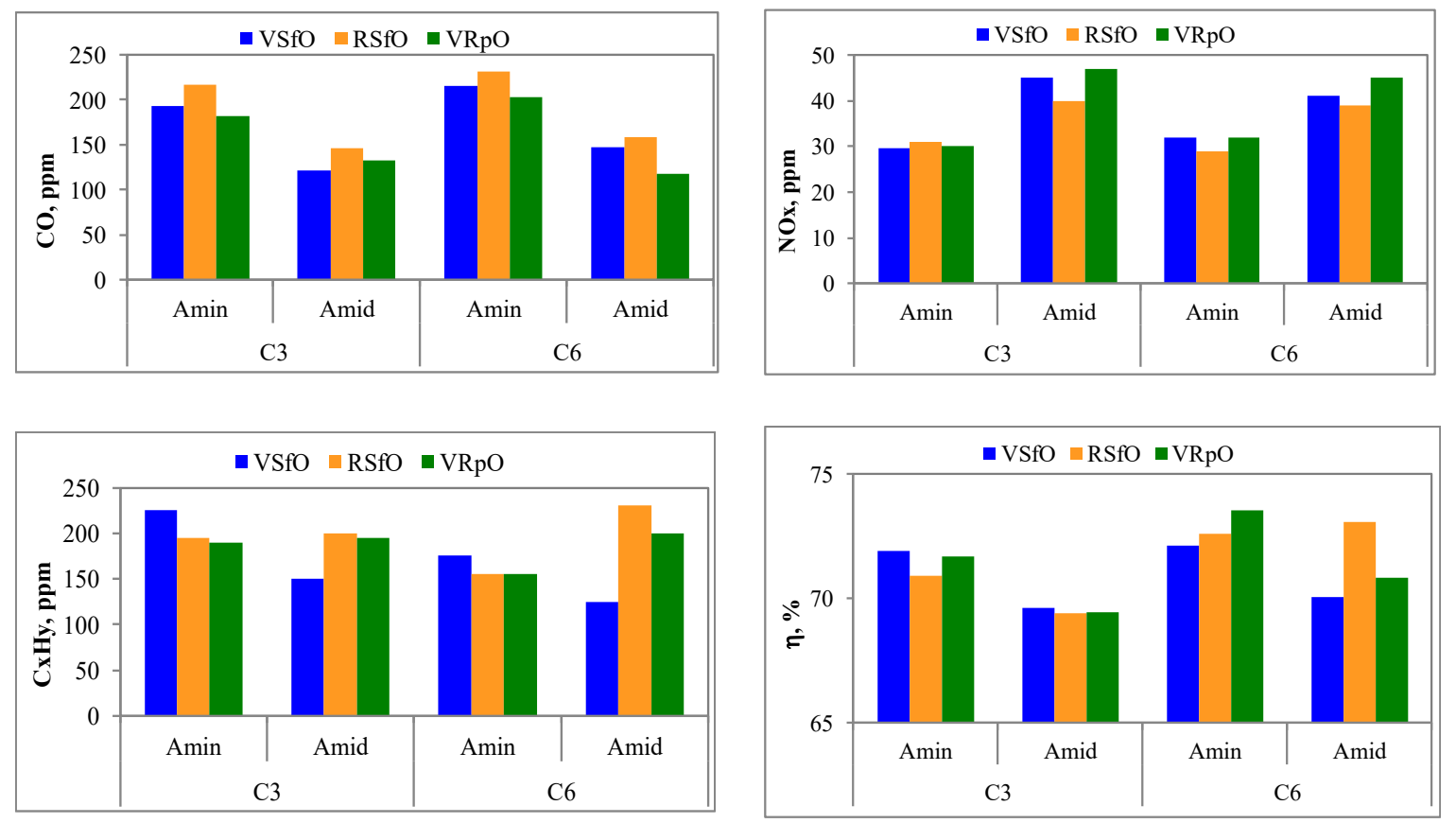

Figure 3. Variations of combustion characteristics with fuel flow and secondary airflow of each VO studied.

It can be seen how the behavior of the three VOs is quite comparable. CO emissions increased when the airflow was reduced for all of them. On the other hand, NOx emissions varied inversely and decreased when the airflow was reduced. Given that VOs contain no organic nitrogen compounds, NOx emissions come from dissociation of nitrogen in the air and the subsequent reaction with oxygen from air. Thus, NOx emissions rose as airflow increased in the combustion chamber. With regard to CxHy emissions, VSfO behaved differently to RSfO and VRpO. The lowest emissions were obtained under conditions C6/Amin for RSfO and VRpO. In contrast, VSfO provided the lowest values for C6/Amid. As for combustion performance, all the VOs present the highest value for conditions $\mathrm{C} 6 /$ Amin. It should be highlighted that although the highest $\mathrm{CO}$ emissions corresponded to the optimal conditions for the rest of the variables (C6/Amin), the values obtained are below those allowed by European legislation. 
In an effort to simplify a comparative study of the results obtained, the authors decided to analyze the mean values of each response variable for each of the factors tested (VO, fuel flow rate and airflow). Bearing in mind the fairly similar behavior of the VOs tested (see Figure 3), the first $\mathrm{VO}$ is not regarded as a significant factor. Therefore, considering secondary airflow and fuel flow rates as the only significant factors, the mean values of the measurements obtained for the three VOs were calculated. In this descriptive statistical study, a coefficient of variation, CV, less than $20 \%$ was considered admissible [28] since the variation of the measure above this value would indicate that the factor is not significant (see the Supplementary Materials).

Figure 4 shows the mean values of the polluting emissions (CO, NOx, $\mathrm{CxHy}$ ) and combustion performance in terms of airflow and fuel flow. It can be seen that although the lowest $\mathrm{CO}$ emissions were obtained for the Amid conditions, those for NOx increased in these conditions, as explained above. CxHy emissions displayed no clear trend, although the lowest values, as with NOx, correspond to C6/Amin conditions. These conditions also resulted in the highest combustion performance values.
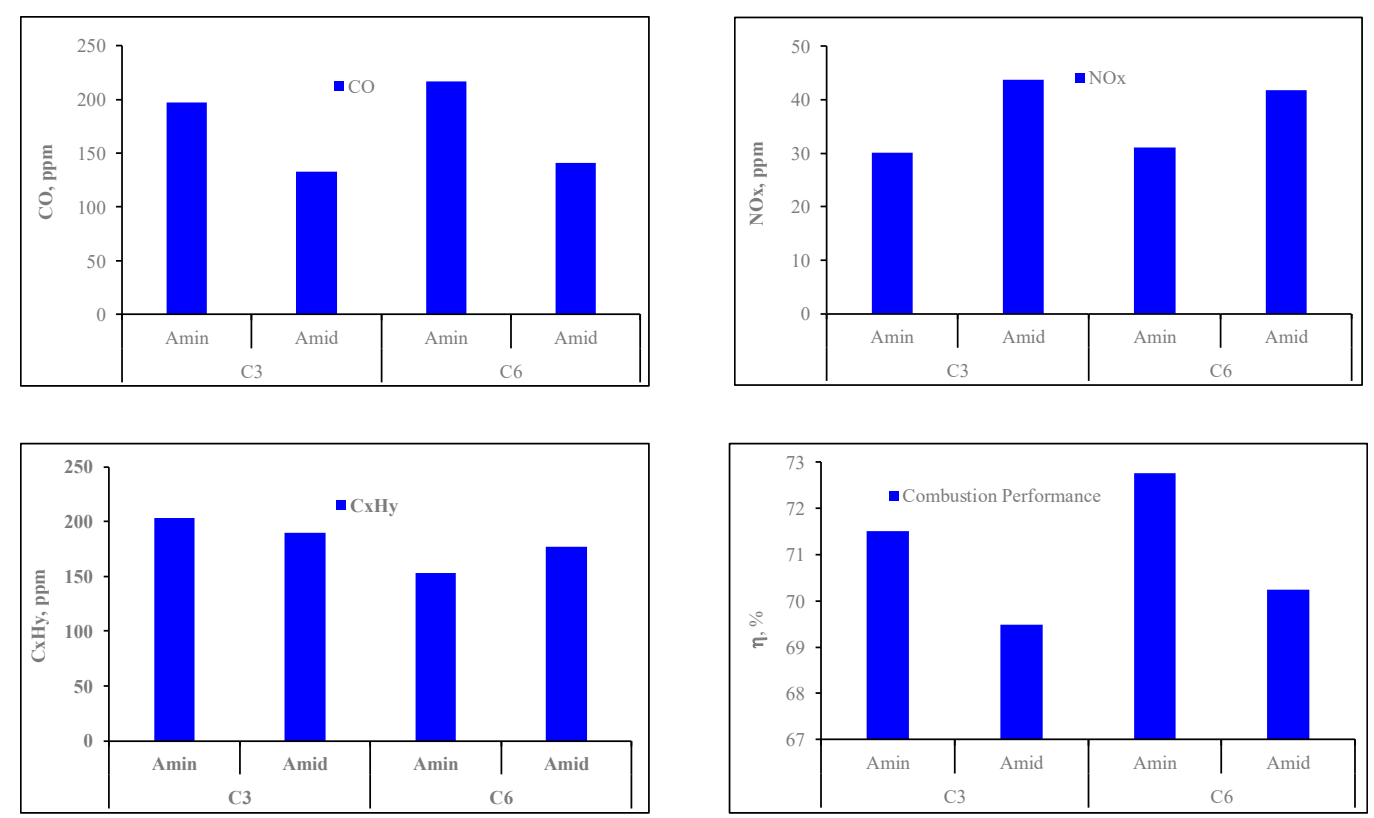

Figure 4. Variations of pollutant emissions and combustion performance in the different burner operating conditions considering that $\mathrm{VO}$ is not a significant factor.

Two statistical studies were performed which considered the type of $\mathrm{VO}$ as a significant factor, and the fuel flow and then the airflow as a non-significant factor (the mean value, standard deviation, and CV can be found in the Supplementary Materials).

The graphic representation of these results (Figure 5) allowed us to evaluate the effect of each factor. The greater the inclination of the line, the greater the effect the factor has on the corresponding response variable. For $\mathrm{CO}$ and NOx emissions, a greater influence of airflow compared to fuel flow could be seen for the three VOs studied. CO emissions decreased when the airflow increased, whereas for NOx emissions, the opposite trend emerged. There was virtually no change in either type of emission when the fuel flow was modified. For CxHy emissions, it could be seen how both the airflow and the fuel flow had a significant influence on emissions levels. With regard to fuel flow, the three vegetable oils evidenced similar behavior, with lower emissions being obtained for C6. In regards to airflow, RSfO and VRpO displayed a similar trend, with lower emissions for A min. The behavior of VSfO is anomalous and the opposite trend emerged. As for combustion performance, the similar inclination of the two lines showed that both factors proved significant for this variable, with maximum values obtained for C6/A min. The best combustion performance was achieved for VRpO. This result 
could be explained on account of the presence of linolenic acid in its composition with three conjugated carbon-carbon double bonds, which are easily oxidized and favor the combustion process.
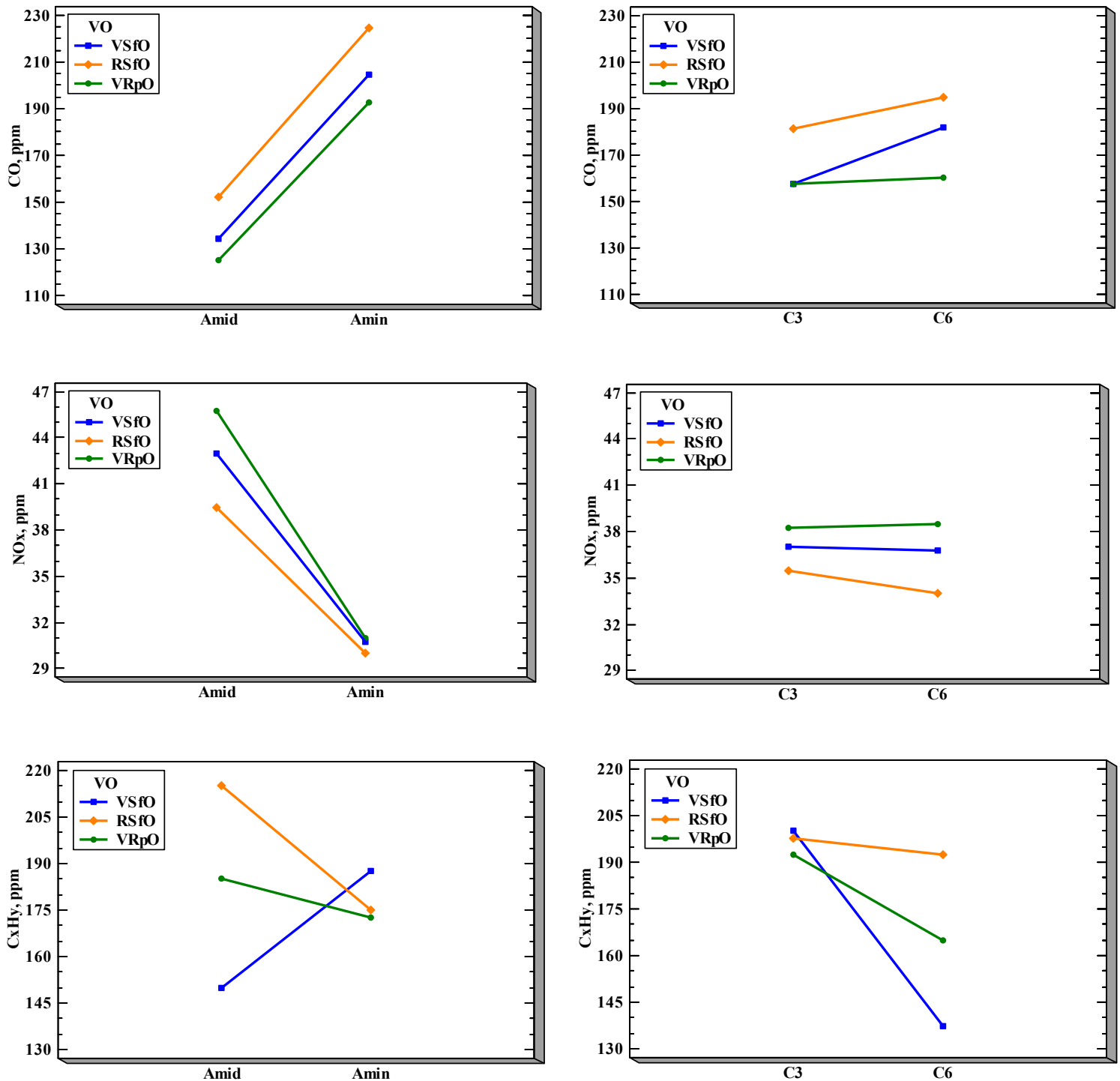

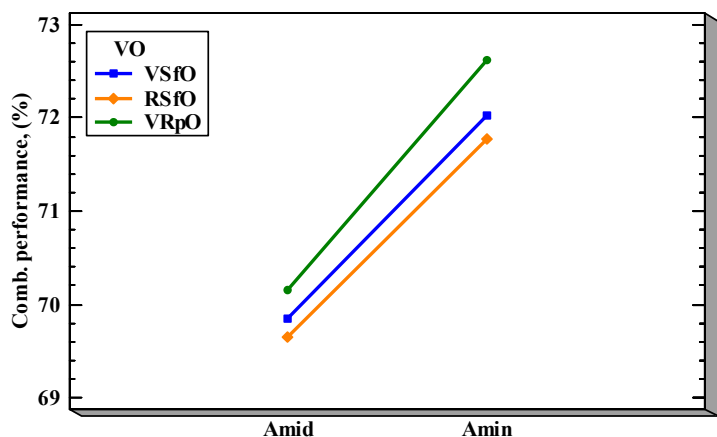

(a)

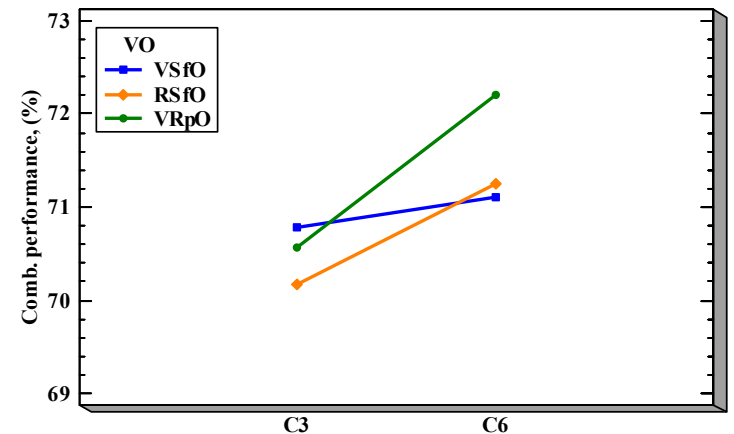

(b)

Figure 5. Variability of combustion characteristics in the different burner operating conditions considering the type of $\mathrm{VO}$ as a significant factor, and (a) the fuel flow, (b) the airflow as a non-significant factor. 


\section{Conclusions}

The combustion tests carried out show that the three biofuels used (VSfO, VRpO and RSfO) display similar behavior in the combustion process. This highlights the fact that the ARCO (BR5) burner is suitable for performing combustion of virgin vegetable oils. This represents a major cost saving, since no refining process is required.

In general, concentrations of $\mathrm{CO}, \mathrm{NOx}$ and $\mathrm{CxHy}$ in the flue gas are below the limits established by European legislation.

The optimal burner operating conditions were maximum fuel flow (C6) and minimum airflow (Amin). In these conditions, the lowest NOx emissions and the highest combustion performance for the three VOs studied (VSfO, RSfO and VRpO) were obtained. Although the CO emissions were the highest for these conditions, the values obtained remained below the lowest limit established ( $\leq 300 \mathrm{ppm}$ ).

A statistical descriptive analysis was performed to determine which factor $(\mathrm{VO}$, fuel flow and air flow) is most influential in the combustion results. Findings show that of the two factors studied, airflow has the greatest influence on $\mathrm{CO}$ and NOx emissions. Both types of emissions evidenced opposing trends: NOx emissions fell when airflow dropped, whereas $\mathrm{CO}$ emissions increased. As for $\mathrm{CxHy}$ emissions and combustion performance, both factors proved to be determinant factors. Combustion performance improves as fuel flow increases and airflow decreases. Emissions of $\mathrm{CxHy}$ follow no clear trend.

In summary, the burner used is suitable for using virgin VOs as biofuels and provides extremely low NOx and acceptable CO emissions with good combustion performance.

Supplementary Materials: The following are available online at http://www.mdpi.com/1996-1073/12/12/2372/s1, Table S1: Technical characteristics of the Testo 350M/XL Gas Analyzer. Table S2: Variations of gas emissions with fuel flow and secondary airflow of each VO studied considering the VO not to be a significant factor (mean values, standard deviation and CV). Table S3: Variations of gas emissions and combustion performance in the different burner operating conditions considering the type of $\mathrm{VO}$ as a significant factor, and the fuel flow (right) and then the airflow (left) as a non-significant factor (mean values, standard deviation and CV).

Author Contributions: Conceptualization, and Writing-Original Draft Preparation, J.S.J.; Methodology, Experiment and Analysis of Results, J.S.J., M.A.S.-T. and Y.A.; Writing-Review and Editing, J.S.J. and Y.A.

Funding: This research was funded by JCyL (European Regional Development Fund; VA272P18) https://search. crossref.org/funding, any errors may affect your future funding.

Conflicts of Interest: The authors declare no conflict of interest.

\section{References}

1. European Parliament and the Council of the European Union. Directive 2003/30/EC on the promotion of the use of biofuels or other renewable fuels for transport. Off. J. Eur. Union 2003, L123, 42-46.

2. Bazooyar, B.; Shariati, A.; Hashemabadi, S.H. Economy of a utility boiler power plant fueled with vegetable oil, biodiesel, petrodiesel and their prevalent blends. Sustain. Prod. Consum. 2015, 3, 1-7. [CrossRef]

3. Bazooyar, B.; Shariati, A.; Hashemabadi, S.H. Characterization and Reduction of NO during the Combustion of Biodiesel in a Semi-industrial Boiler. Energy Fuels 2015, 29, 6804-6814. [CrossRef]

4. Bazooyar, B.; Ebrahimzadeh, E.; Jomekian, A.; Shariati, A. NOx Formation of Biodiesel in Utility Power Plant Boilers. Part A: Influence of Fuel Characteristics. Energy Fuels 2014, 28, 3778-3792. [CrossRef]

5. Bazooyar, B.; Ghorbani, A.; Shariati, A. Combustion performance and emissions of petrodiesel and biodiesels based on various vegetable oils in a semi industrial boiler. Fuel 2011, 90, 3078-3092. [CrossRef]

6. Pereira, C.; Wang, G.; Costa, M. Combustion of biodiesel in a large-scale laboratory furnace. Energy 2014, 74, 950-955. [CrossRef]

7. Kermes, V.; Belohradsky, P. Biodiesel (EN 14213) heating oil substitution potential for petroleum based light heating oil in a $1 \mathrm{MW}$ stationary combustion facility. Biomass Bioenergy 2013, 49, 10-21. [CrossRef]

8. Macor, A.; Pavanello, P. Performance and emissions of biodiesel in a boiler for residential heating. Energy 2009, 34, 2025-2032. [CrossRef] 
9. Tashtoush, G.; Al-Widyan, M.I.; Al-Shyoukh, A.O. Combustion performance and emissions of ethyl ester of a waste vegetable oil in a water-cooled furnace. Appl. Therm. Eng. 2013, 23, 285-293. [CrossRef]

10. Ghorbani, A.; Bazooyar, B. Optimization of the combustion of SOME (soybean oil methyl ester), B5, B10, B20 and petrodiesel in a semi industrial boiler. Energy 2012, 44, 217-227. [CrossRef]

11. Ghorbani, A.; Bazooyar, B.; Shariati, A.; Jokar, S.M.; Ajami, H.; Naderi, A. A comparative study of combustion performance and emission of biodiesel blends and diesel in an experimental boiler. Appl. Energy 2011, 88, 4725-4732. [CrossRef]

12. Ng, H.K.; Gan, S. Combustion performance and exhaust emissions from the non-pressurised combustion of palm oil biodiesel blends. Appl. Therm. Eng. 2010, 30, 2476-2484. [CrossRef]

13. González-González, J.F.; Al-Kassir, A.; San José, J.; González, J.; Gómez-Landero, A. Study of combustion process of biodiesel/gasoil mixture in a domestic heating boiler of $26.7 \mathrm{~kW}$. Biomass Bioenergy 2014, 60, 178-188. [CrossRef]

14. San José, J.; Al-Kassir, A.; López-Sastre, J.A.; Gañán, J. Analysis of biodiesel combustion in a boiler with pressure operated mechanical pulverisation burner. Fuel Process. Technol. 2011, 92, 271-277.

15. Lee, S.W.; Herage, T.; Young, B. Emission reduction potential from the combustion of soy methyl ester fuel blended with petroleum distillate fuel. Fuel 2004, 83, 1607-1613. [CrossRef]

16. López-Sastre, J.A.; San José-Alonso, J.F.; Romero-Ávila, C.; López, E.J.; Rodríguez-Alonso, C. A study of decrease in fossil CO2 emissions of energy generation by using vegetable oils as combustible. Build. Environ. 2003, 38, 129-133. [CrossRef]

17. San José-Alonso, J.F.; Romero-Ávila, C.; López Sastre, J.A.; Izquierdo-Iglesias, C.; López, E.J. Using mixtures of diesel and sunflower oil as fuel for heating purposes in Castilla y León. Energy 2005, 30, 573-582.

18. San José-Alonso, J.F.; López-Sastre, J.A.; Rodríguez-Duque, E.; López, E.J.; Romero-Ávila, C. Combustion of Soya Oil and Diesel Oil Mixtures for Use in Thermal Energy Production. Energy Fuels 2008, 22, 3513-3516. [CrossRef]

19. San José-Alonso, J.; López-Sastre, J.A.; Romero-Ávila, C.; López, E.J.A. note on the combustion of blends of diesel and soya, sunflower and rapeseed vegetable oils in a light boiler. Biomass Bioenergy 2008, 32, 880-886. [CrossRef]

20. San José-Alonso, J.; López-Sastre, J.A.; Romero-Ávila, C.; López, E.J. Combustion of rapeseed oil and diesel oil mixtures for use in the production of heat energy. Fuel Process. Technol. 2006, 87, 97-102. [CrossRef]

21. San José-Alonso, J.F.; Gobernado-Arribas, I.; Alonso-Miñambres, S. Study of combustion in residential oil burning equipment of animal by-products and derived products not intended for human consumption. Int. J. Energy Environ. Eng. 2013, 4, 31-44. [CrossRef]

22. San José-Alonso, J.F.; Romero-Ávila, C.; San José-Hernández, L.M.; Al-Kassir, A. Characterizing biofuels and selecting the most appropriate burner for their combustion. Fuel Process. Technol. 2012, 103, 39-44. [CrossRef]

23. San José, J.; Sanz-Tejedor, M.A.; Arroyo, Y. Effect of fatty acid composition in vegetable oils on combustion processes in an emulsion burner. Fuel Process. Technol. 2015, 130, 20-30. [CrossRef]

24. Sanz-Tejedor, M.A.; Arroyo, Y.; San José, J. Influence of Degree of Unsaturation on Combustion performance and Flue Gas Emissions of Burning Five Refined Vegetable Oils in an Emulsion Burner. Energy Fuels 2016, 30, 7357-7366. [CrossRef]

25. San José, J.; Sanz-Tejedor, M.A.; Arroyo, Y. Spray Characteristics, Combustion Performance, and Palm Oil Emissions in a Low-Pressure Auxiliary Air Fluid Pulverization Burner. Energy Fuels 2018, 32, 11502-11510. [CrossRef]

26. American Society of Heating, Refrigerating and Air-Conditioning Engineers. ASHRAE Handbook Fundamentals; American Society of Heating, Refrigerating and Air-Conditioning Engineers, Inc.: Atlanta, GA, USA, 2013; Chapter 28.

27. European Parliament and of the council of the European Union. Directive 2010/75/EU on industrial emissions (integrated pollution prevention and control). Off. J. Eur. Union 2010, L334, 17.

28. Mann, P.S. Introductory Statistics, 2nd ed.; Wiley: Hoboken, NJ, USA, 1995.

(C) 2019 by the authors. Licensee MDPI, Basel, Switzerland. This article is an open access article distributed under the terms and conditions of the Creative Commons Attribution (CC BY) license (http://creativecommons.org/licenses/by/4.0/). 